\title{
Structural deterioration of the cryopreserved mitral homograft valve
}

\author{
Silvio Olivito, MD, Stéphanie Lalande, MD, Francesco Nappi, MD, Nadjib Hammoudi, MD, \\ Cosimo D'Alessandro, MD, Pierre Fouret, MD, and Christophe Acar, MD
}

Objective: The aim of this study was to evaluate the long-term fate of the cryopreserved mitral homograft focusing on structural valve deterioration.

Methods: Homograft replacement of the mitral valve was performed in 106 patients. The causes of mitral disease were rheumatic disease $(n=75)$, endocarditis $(n=24)$, and others $(n=7)$. There were 40 partial homografts and 66 total homografts.

Results: Mean follow-up was $9.3+4.7$ years (up to 17.8 years). There were 5 early ( $<3$ months) and 15 late deaths. There have been 5 early ( $<3$ months) and 30 late reoperations. Five patients had endocarditis, and 5 patients had an ischemic/hemorrhagic event. Compared with baseline, follow-up echography showed progression of mitral regurgitation grade (from 0.4 to $1.3 ; P<.001$ ) with stenosis (elevated gradient: from 3.9 to $7.0 \mathrm{~mm} \mathrm{Hg}$; $P<.001$ ) and decreased valve area (from 2.3 to $1.7 \mathrm{~cm}^{2}, P<.001$ ). Freedom from structural valve deterioration was $90 \%, 76 \%$, and $65 \%$ at 5,10 , and 15 years, respectively. Structural valve deterioration was more frequent in total homografts $(P=.018$ vs partial homografts) and in case of pregnancy $(P=.016$ vs no pregnancy). Stenosis related to structural valve deterioration was more pronounced for age less than 40 years $(P=.03)$ and ring size $30 \mathrm{~mm}$ or less $(P=.002)$. Pathologic analysis of the explanted homografts almost invariably showed dense fibrosis with calcification and no cellularity.

Conclusions: Mitral homografting was accomplished with early echographic results similar to those of valve repair. Structural valve deterioration produced mixed stenosis with insufficiency, and its incidence was comparable to that of bioprostheses structural valve deterioration. An improvement in the preservation mode of valvular homografts is warranted. (J Thorac Cardiovasc Surg 2012;144:313-20)

Supplemental material is available online.

For many years, allogenous transplantation of the mitral valve has remained an open question. ${ }^{1}$ In the beginning of the 1990s, significant advances were reported, such as tricuspid valve replacement with a mitral homograft ${ }^{2}$ and partial mitral valve replacement with a homograft segment. ${ }^{3}$ Isolated cases of complete mitral homograft replacement ${ }^{4}$ were then reported, including the description from our group of an original technique based on a side-to-side suturing of the homograft papillary muscles with multiple interrupted stitches together with prosthetic ring implantation. ${ }^{5}$ In 1996, the technique applied in a series of 43 patients proved to be safe and reproducible. ${ }^{6}$ Pitfalls that were responsible for occasional early homograft failure in the

\footnotetext{
From the Department of Cardiac Surgery, Hôpital Pitié-Salpétrière, Paris, France. Disclosures: Authors have nothing to disclose with regard to commercial support. Received for publication April 9, 2011; revisions received May 9, 2011; accepted for publication June 6, 2011; available ahead of print Aug 22, 2011.

Address for reprints: Christophe Acar, MD, Department of Cardiac Surgery, Hôpital Pitié-Salpétrière, 50-52 Boulevard Vincent Auriol, 75013 Paris, France (E-mail: c.acar@psl.aphp.fr).

$0022-5223 / \$ 36.00$

Copyright (c) 2012 by The American Association for Thoracic Surgery doi:10.1016/j.jtcvs.2011.06.041
}

learning phase have been addressed. ${ }^{6}$ More recently, clinical and echographic results at intermediate-term followup (mean: 4.3 years) in a series of 104 patients were reported. $^{7}$ The aim of the present study was to evaluate the durability of the cryopreserved mitral homograft valve over a period extending up to 18 years focusing on structural valve deterioration.

\section{MATERIALS AND METHODS \\ Patients}

From February 1993 to May 2003, 106 patients (female, $n=67$; male, $\mathrm{n}=49$ ) underwent mitral homograft replacement. The mean age was $38.1 \pm 15$ years (10-71 years) with 11 patients aged less than 18 years. Electrocardiography showed sinus rhythm in 87 patients and chronic atrial fibrillation in 19 patients. The cause of mitral valve disease was rheumatic valve disease $(n=75)$; bacterial endocarditis $(n=24)$, including 5 cases involving a previously diseased mitral valve (rheumatic valve disease: $\mathrm{n}=3$, Barlow disease: $\mathrm{n}=2$ ); autoimmune disorder $(\mathrm{n}=4)$ (systemic lupus: $\mathrm{n}=2$, primary antiphospholipid syndrome: $\mathrm{n}=1$, juvenile polyarthritis: $\mathrm{n}=1)$; marasmic endocarditis $(\mathrm{n}=1)$; Barlow disease $(\mathrm{n}=1)$; and congenital stenosis $(n=1)$. Twenty-six patients had previously undergone mitral valve operations: repair $(n=23)$ or replacement $(n=3)$. The rationale for choosing a homograft was as follows: age less than 18 years $(\mathrm{n}=11)$, woman of childbearing age $(\mathrm{n}=38)$, contraindication to oral anticoagulation $(\mathrm{n}=50)$, and endocarditis $(\mathrm{n}=24)$.

\section{Surgical Technique}

The technical details of mitral homograft insertion have been described. ${ }^{7,8}$ Surgical strategy was based on the extent of valve lesions. 


\section{Abbreviation and Acronym \\ $\mathrm{MR}=$ mitral regurgitation}

Partial homograft replacement was performed in 40 cases using an anterior leaflet patch $(\mathrm{n}=10)$ or a mitral hemivalve with reimplantation of the corresponding papillary muscle $(\mathrm{n}=30)$. Patients with endocarditis preferentially underwent partial homograft replacement (16/24). Complete homograft replacement was achieved in 66 cases. Prosthetic ring annuloplasty was realized in all patients with a Carpentier-Edwards Physio Ring (Edwards Lifesciences LLC, Irvine, Calif) $(\mathrm{n}=72)$ or flexible Duran ring (Medtronic, Minneapolis, Minn) $(\mathrm{n}=34)$. Ring size was reported by the intercommissural distance given by the CarpentierEdwards obturator or the Duran obturator $+2 \mathrm{~mm}$. Mean ring size was $31.4 \pm 1.7 \mathrm{~mm}(28-36 \mathrm{~mm})$. Because of smaller body size in the pediatric group, ring size in patients aged less than 40 years was smaller than in older patients $\left(31.1 \pm 1.8\right.$ vs $\left.31.7 \pm 1.7 \mathrm{~cm}^{2}, P=.04\right)$. Likewise, ring size was smaller in complete than in partial homografts $(31.2 \pm 1.7$ vs $31.8 \pm$ $\left.1.7 \mathrm{~cm}^{2}, P=.01\right)$.

Associated surgery included aortic valve repair $(n=5)$ or aortic valve replacement with a homograft $(\mathrm{n}=10)$, tricuspid valve annuloplasty $(\mathrm{n}=7)$ or tricuspid valve replacement with a mitral homograft $(\mathrm{n}=2)$, pulmonary vein isolation $(\mathrm{n}=4)$, and coronary artery bypass $(\mathrm{n}=1)$.

\section{Clinical Follow-up}

Data were periodically collected at spaced time intervals ( $\sim 5$ years). In addition, cross-sectional analysis in a retrospective manner was carried out over the second semester of the year 2010. Clinical follow-up was obtained by physical examination or by phone directly from the patient or the patient's general practitioner or cardiologist.

\section{Echocardiography}

Baseline echocardiography was performed immediately after the operation at the time of discharge. Follow-up echocardiography was obtained at the latest periodical examination or immediately before redo surgery. Mitral valve regurgitation was graded according to jet extension. Transvalvular gradient was measured by Doppler, and surface valve area was calculated according to the Hattle formula.

\section{Structural Valve Deterioration}

Structural valve deterioration was defined according to the guidelines ${ }^{9}$ as intrinsic changes to the homograft, such as calcification and tear leading to dysfunction. Early technical failure and endocarditis were excluded. Diagnosis of structural deterioration relied on the aspect of the valve at reoperation and on echocardiographic surveillance. It was considered when echography showed leaflet thickening/ calcification together with severe dysfunction: regurgitation grade 3 or 4 , mean gradient greater than $10 \mathrm{~mm} \mathrm{Hg}$, or valve area less than $1 \mathrm{~cm}^{2}$.

\section{Statistical Analysis}

Descriptive data for continuous variables were presented as means with standard deviation. Patient groups were compared by chi-square test for categoric values and Student $t$ test for continuous variables. Survival, freedom from reoperation, and freedom from structural deterioration were estimated according to the Kaplan-Meier method. When structural valve deterioration was detected by echocardiography, the date of the examination was used for constructing the Kaplan-Meier curve.

\section{RESULTS}

Follow-up was $96.2 \%$ complete (4 patients lost to follow-up). The mean duration of the observation period was $9.3 \pm 4.7$ years $(0.4-17.8$ years $)$.

\section{Survival}

There were 5 early deaths $(4.7 \%)$ in the perioperative period $(<3$ months). Fifteen other patients ultimately died. Cardiac causes of death were congestive heart failure $(\mathrm{n}=2)$, pulmonary embolus $(\mathrm{n}=1)$, and death at reoperation $(\mathrm{n}=3)$. The other causes of mortality were cancer $(\mathrm{n}=6)$ (laryngeal $\mathrm{n}=1$, lung $\mathrm{n}=2$, digestive $\mathrm{n}=2$, and urogenital $\mathrm{n}=1$ ), human immunodeficiency virus-related infection $(\mathrm{n}=1)$, trauma with cerebral hemorrhage $(\mathrm{n}=1)$, and degenerative neuropathy $(\mathrm{n}=1)$. Survival according to the Kaplan-Meier estimate was $88 \%, 85 \%$, and $80 \%$ at 5,10 , and 15 years, respectively (Figure 1).

\section{Reoperation}

Incidence. There were 5 early reoperations within 3 months for mitral homograft failure. All were technically related: restriction due to improper papillary muscle positioning $(\mathrm{n}=3)$, leaflet suture dehiscence $(\mathrm{n}=1)$, and chordal rupture due to erosion by the suture material $(\mathrm{n}=1){ }^{6,7}$ There were 30 late reoperations ( $>3$ months) after a mean period of 7.6 years (1.3-13.9 years) for an overall $67.0 \%$ freedom of reoperation. Late reoperations were primarily indicated for degeneration of the mitral homograft $(\mathrm{n}=23)$, bacterial endocarditis $(\mathrm{n}=5)$, and aortic valve disease $(n=2)$. Kaplan-Meier freedom from reoperation was $88 \%, 80 \%$, and $64 \%$ at 5,10 , and 15 years, respectively (Figure 1).

Determinants of reoperation were studied for age $(<40 \mathrm{vs}$ $>40$ years), homograft technique (total vs partial homograft), prosthetic ring size ( $\leq 30 \mathrm{~mm}$ vs larger size), associated aortic valve surgery, endocarditis as primary indication, and pregnancy. There was no statistically significant difference among subgroups (Table E1).

When specifically considering patients in the pediatric age group $(<18$ years), there was a trend toward a higher rate of reoperation $(6 / 11$ or $54.5 \%)(P=.11)$. Likewise, the use of a $28-\mathrm{mm}$ prosthetic ring size was associated with a higher risk of reoperation $(P=.003$ vs larger size rings).

Technique and results. Reoperation after mitral homograft replacement was not particularly challenging. The mitral homograft was replaced in all cases except in 1 patient with no dysfunction of an anterior leaflet homograft patch who required aortic valve replacement. In another reoperation for aortic valve dysfunction at 10 years, prophylactic replacement of a mildly dysfunctioning mitral homograft was carried out. 

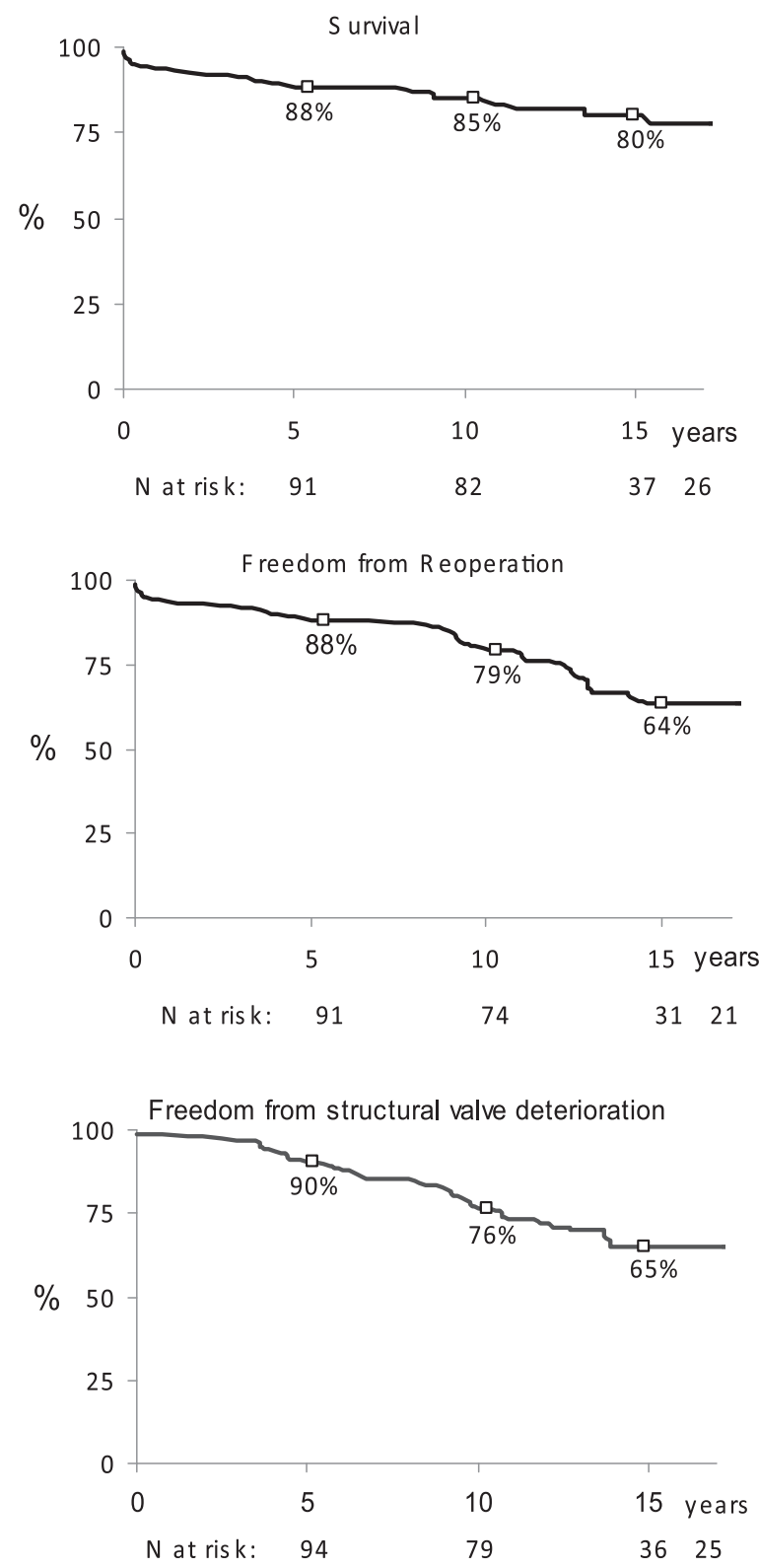

FIGURE 1. Kaplan-Meier estimate of survival, freedom from reoperation, and freedom from structural valve deterioration in 106 patients with a cryopreserved mitral homograft valve.

The first step of the procedure was prosthetic ring removal, and then the whole mitral homograft valve was excised. Because of the extent of calcifications, it was seldom possible to retain basal chordae of the homograft. Mitral valve replacement was performed with a mechanical prosthesis in 20 cases and a bioprosthesis in 14 cases. Associated aortic valve replacement was realized in 7 cases for repair failure $(n=2)$, homograft degeneration $(n=3)$, and progression of rheumatic disease $(n=2)$. Tricuspid valve surgery was required in 13 cases: annuloplasty $(\mathrm{n}=12)$ and replacement with a bioprosthesis $(\mathrm{n}=1)$.
The need for tricuspid valve surgery $(13 / 35)$ was greater in reoperations than at primary surgery $(7 / 106)(P<.001)$.

Mortality at reoperation was $8.6 \%(\mathrm{n}=3 / 35)$ and not statistically higher than that of the first operation $(P=.39)$. Causes of death were uncontrolled sepsis secondary to endocarditis, bleeding at sternal reentry, and left ventricular dysfunction related to technical problems in replacing a calcified aortic homograft root.

\section{Endocarditis}

Bacterial endocarditis occurred in 5 patients, who all required reoperation, and freedom from endocarditis was $95.3 \%$. Patients initially undergoing operation for endocarditis had a 10 -fold higher risk (5/24) to experience a new sepsis than patients primarily undergoing operation for another cause $(2 / 82)(P=.04)$.

\section{Thromboembolic and Hemorrhagic Complication}

Five patients had thromboembolic complications: silent thrombus attached to the ring $(\mathrm{n}=2)$ and transient ischemic attack $(\mathrm{n}=3)$. Two patients had severe bleeding (intramuscular hematoma and gastrointestinal bleeding). All patients were treated medically. Freedom from thromboembolic/ hemorrhagic complication was $93.4 \%$.

\section{Functional Status}

Of 51 patients alive without reoperation, functional class according to the New York Heart Association was I $(\mathrm{n}=37)$, II $(\mathrm{n}=9)$, and III $(\mathrm{n}=5)$. Thirty-five patients were in sinus rhythm, and 16 patients were in atrial fibrillation ( $P=.05$ vs atrial fibrillation at discharge). Throughout the study period, 9 women bearing a mitral homograft gave birth to 15 healthy children, and there was 1 spontaneous abortion.

\section{Echocardiographic Study}

In 5 cases, echocardiography at discharge showed grade 3 or 4 mitral regurgitation (MR), and early reoperation was carried out. In the 92 remaining cases, baseline echography showed a normal mitral valve function (Table 1). Left atrial diameter and left ventricular diastolic diameter were $48.0 \pm$ $12 \mathrm{~mm}$ and $50.3 \pm 6.7 \mathrm{~mm}$, respectively. Left ventricular ejection fraction was $60 \% \pm 8 \%$. When considering subcategories, there was no difference in homograft valve function at discharge for age less than 40 years versus more than 40 years, partial versus total homograft, and ring size 30 $\mathrm{mm}$ or less versus greater than $30 \mathrm{~mm}$.

Echocardiography follow-up was obtained in all 92 cases after a mean period of $7.6 \pm 4.1$ years $(0.3-16.2$ years). It showed a variable degree of leaflet thickening together with a progressively worsening regurgitant and stenotic process. When compared with baseline data at discharge, the degree of MR was significantly increased (Table 1). Likewise, transvalvular gradient was higher and surface valve 
TABLE 1. Echocardiographic evaluation of mitral homograft valve function

\begin{tabular}{|c|c|c|c|c|c|c|}
\hline \multirow{2}{*}{$\begin{array}{l}\text { Echocardiography } \mathbf{n}=\mathbf{9 2} \\
\text { At discharge }\end{array}$} & \multicolumn{2}{|c|}{ MR grade } & \multicolumn{2}{|c|}{ Mean gradient (mm Hg) } & \multicolumn{2}{|c|}{ Valve area $\left(\mathrm{cm}^{2}\right)$} \\
\hline & $0.4 \pm 0.5$ & $P<.001$ & $3.9 \pm 1.5$ & $P<.001$ & $2.3 \pm 0.5$ & $P<.001$ \\
\hline At 8.3-y follow-up & $1.3+1.2$ & & $7.0+3.9$ & & $1.7 \pm 0.6$ & \\
\hline \multicolumn{7}{|l|}{ Age } \\
\hline$<40 \mathrm{y}$ & $1.3 \pm 1.3$ & $P=.49 \mathrm{NS}$ & $8.1 \pm 4.2$ & $P<.001$ & $1.7 \pm 0.6$ & $P=.03$ \\
\hline$>40 \mathrm{y}$ & $1.3 \pm 1.2$ & & $5.4 \pm 2.4$ & & $1.9 \pm 0.4$ & \\
\hline \multicolumn{7}{|l|}{ Homograft technique } \\
\hline Total & $1.4 \pm 1.2$ & $P=.07 \mathrm{NS}$ & $7.7 \pm 4.1$ & $P=.004$ & $1.7 \pm 0.6$ & $P=.02$ \\
\hline Partial & $1.0 \pm 1.3$ & & $5.6 \pm 2.6$ & & $1.9 \pm 0.5$ & \\
\hline \multicolumn{7}{|l|}{ Ring size } \\
\hline$\leq 30 \mathrm{~mm}$ & $1.4 \pm 1.3$ & $P=.59 \mathrm{NS}$ & $8.2 \pm 4.1$ & $P=.002$ & $1.6 \pm 0.5$ & $P=.002$ \\
\hline$>30 \mathrm{~mm}$ & $1.2 \pm 1.2$ & & $5.9 \pm 3.1$ & & $1.9 \pm 0.6$ & \\
\hline
\end{tabular}

NS, Not significant.

area was reduced (Table 1). Mean systolic pulmonary artery pressure was increased $(37.6 \pm 9.9 \mathrm{~mm} \mathrm{Hg})(P=.001)$. Left heart chamber size remained unchanged: atrial diameter: $49.0 \pm 8.4 \mathrm{~mm}(P=.54)$, ventricular diastolic diameter: $50.8 \pm 7.3 \mathrm{~mm}(P=.54)$, and ejection fraction: $59.1 \% \pm$ $8.6 \%(P=.52)$.

There was no obvious parameter contributing to mitral homograft regurgitation (Table 1). In contrast, the onset of homograft stenosis was markedly accelerated with a higher gradient and a smaller valve area in patients aged less than 40 years versus older patients, with a total versus partial homograft, and with a ring size $30 \mathrm{~mm}$ or less compared with larger ring sizes (Table 1).

\section{Structural Valve Deterioration}

Structural deterioration was detected at explantation during reoperation in 23 cases. With time, almost all mitral homografts showed some degree of leaflet thickening on echocardiography. In 10 other cases, structural deterioration was asserted by echocardiography showing gross thickening/calcification together with severe homograft dysfunction. These patients were asymptomatic, denied surgery, or presented a contraindication due to comorbidities. Altogether, structural deterioration was observed in 33 cases with predominant insufficiency $(\mathrm{n}=6)$, predominant stenosis $(n=12)$, or mixed disease $(n=15)$. Structural deterioration was more frequent in total than in partial homografts $(P=.018)$, in non-endocarditis than in endocarditis cases $(P=.02)$, and in patients who were pregnant $(P=.016$ vs no pregnancy) (Table E2). Age, ring size, and associated aortic valve surgery did not significantly influence structural valve deterioration. Freedom from structural mitral homograft deterioration according to the Kaplan-Meier estimate was $90 \%, 76 \%$, and $65 \%$ at 5,10 , and 15 years, respectively (Figure 1).

\section{Histopathology}

Pathologic examination of the mitral homografts explanted for degeneration almost invariably showed the same pattern; the homograft leaflets were rigid, thickened, and calcified with no commissural fusion (Figure 2). The same was observed on partial homografts, but the remaining segments of the native valve were most frequently pliable and stenosis was less pronounced. In occasional places, the homograft leaflet tissue was pellucid (Figure 2). The involvement of the chordae was variable. Most frequently, those were thickened and calcified particularly at their insertion on the leaflets (Figure 3). Oftentimes, the proximal

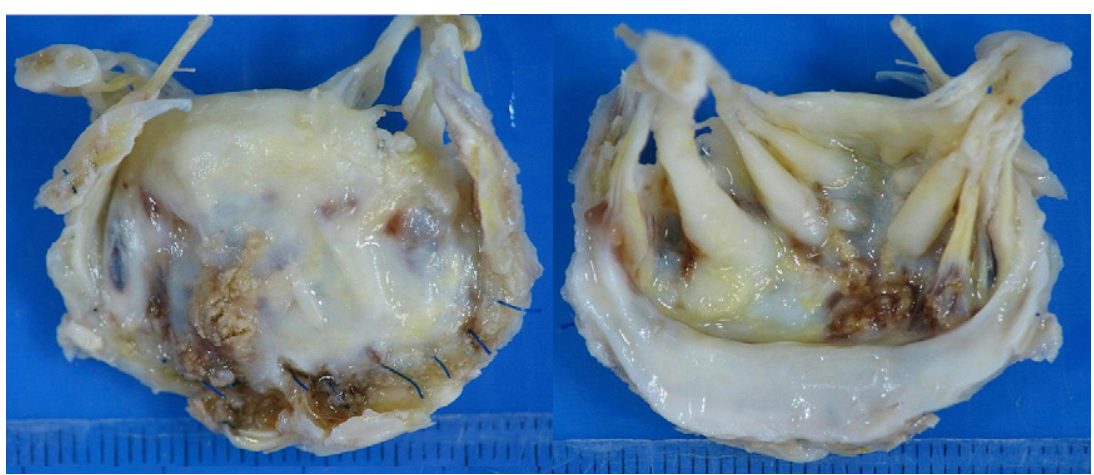

FIGURE 2. Cryopreserved mitral homograft explant at 14 years: Leaflet fibrosis with multiple calcareous nodules. In places, the leaflet tissue is pellucid. Chordae tendineae are markedly thickened, particularly at their attachment to the leaflets, whereas their proximal part is relatively spared. 


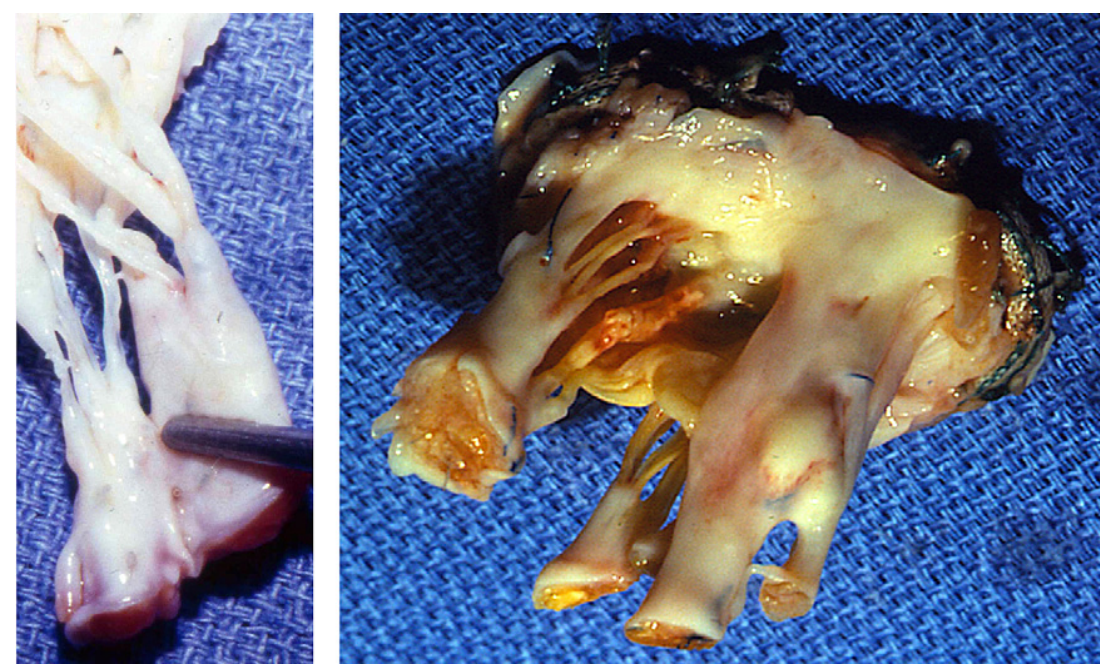

FIGURE 3. Cryopreserved mitral homograft at 7 and 10 years. Left: Complete healing with fibrotic scar of the grafted muscle. The chordae are thin at their attachment to the papillary muscle. Right: Considerable thickening with fusion and calcification of the chordae.

part of the chordae attached to the papillary muscles remained thin. In 2 cases, rupture of accessory chordae was observed. The attachment of the papillary muscles to the host's left ventricle was invariably remarkably strong (Figure 3). The only remnant of the homograft muscles was a fibrotic scar at the apex of the recipient's papillary muscles.

Microscopic analysis of the homograft leaflet tissue showed a destruction of the normal trilaminar architecture (Figure 4). All layers were invaded by a dense fibrosis that was encrusted with calcium deposits. Except for 1 explant at 2 years in a child with a severe inflammatory reaction, there was no sign of immune-mediated reaction in the other valves. High magnification revealed that endothelial cells were virtually absent and that cellularity within fibrosis was extremely poor (Figure 4).

\section{DISCUSSION}

Over the past decade, many isolated cases of mitral valve homograft, particularly in those with endocarditis ${ }^{10,11}$ or in children, ${ }^{12}$ and small series with short-term follow-up ${ }^{13,14}$ have been published. Intermediate-term results (5 years) have been a matter of controversy. Some series in which a prosthetic ring was parsimoniously used have reported negative results. ${ }^{15,16}$ In contrast, mid-term results in our experience and in other groups were comparable to those of bioprostheses in a cohort of young patients. ${ }^{7,17}$

Early valve failure as observed during the learning phase in a few mitral homografts was related to the surgical technique and has been addressed in previous reports. ${ }^{6,7}$ The present study was designed to assess late reoperation focusing on structural valve deterioration. At 15 years, one third of patients have undergone reoperation. The most frequent indication for late reoperation was degeneration of the mitral homograft. However, a few cases of infectious endocarditis on the homograft were observed, particularly in those patients who primarily underwent operation for a first episode of endocarditis (10-fold increased risk). In some cases, reoperation was chiefly undertaken for aortic valve disease, which oftentimes had been already surgically treated. The mitral homograft that was usually dysfunctioning was simultaneously replaced. However, in 1 late reoperation, prophylactic replacement of a normally functioning mitral homograft was performed to obviate the risk of secondary degradation.

From a technical standpoint, reintervention on mitral homografts was not particularly difficult. As in late reoperation after repair, the prosthetic ring was removed as a first step. Fibrocalcareous involvement of the homograft did not raise any problem during valve apparatus excision. In comparison, reintervention on aortic homografts is usually more challenging ${ }^{18} ; 1$ death in our series was due to technical difficulty in replacing an entirely calcified aortic homograft root. Mortality of reoperation after mitral homograft $(8.6 \%)$ did not substantially differ from reported rates for reintervention on bioprostheses. ${ }^{19}$

Kaplan-Meier freedom from reoperation was $88 \%$, $80 \%$, and $64 \%$ at 5,10 , and 15 years, respectively. Statistical analysis of reoperation risk factors failed to identify any determinant parameter (Table E1) except for age less than 18 years, as suggested in a previous study, ${ }^{20}$ and prosthetic ring size of $28 \mathrm{~mm}$.

Mitral homograft valve function was periodically assessed using echocardiography. When evaluated early in the postoperative period, mitral homograft valve function closely mimicked that of a native valve having undergone repair with annuloplasty (Table 1). A few years later, almost all homografts displayed some leaflet thickening as a result 

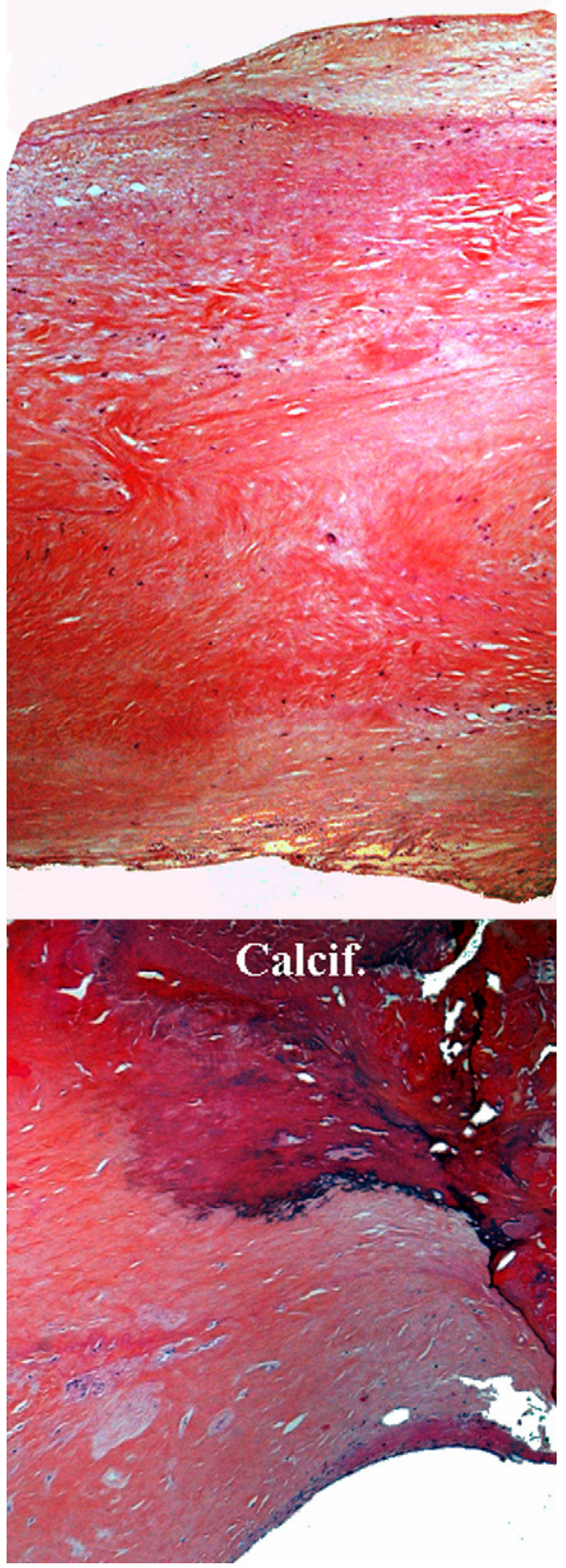

FIGURE 4. Microscopic views of a cryopreserved mitral homograft explant at 14 years. Top: Severe fibrosis with complete loss of the normal trilaminar architecture. Bottom: Higher magnification showing calcium deposit (purple) amid fibrosis. Note the complete absence of cellularity within the collagen matrix with no endothelial cell.

of a degenerative process (Figure 5), and a more or less rapidly evolving dysfunction took place resulting in a leaking and stenotic valve. Echocardiography at the end of the study period showed an increase in the MR grade and mean transvalvular gradient, and a reduction of the valve area (Table 1). Although the systolic pulmonary pressure was perceptibly elevated, it did not affect left ventricle size and function.
The diameter of the left atrium remained unchanged throughout the follow-up period, but the prevalence of atrial fibrillation increased.

At 10 years, 1 of 4 mitral valve homografts was the site of structural deterioration (Figure 1). Although the increased rate of structural deterioration in patients aged less than 40 years did not reach statistical significance (Table E2), the stenotic process was clearly accelerated with a higher gradient and lower valve area compared with older patients (Table 1). Progression toward stenosis is typical of structural deterioration and does not usually exist in endocarditis. Thus, it is indisputable that degeneration of mitral homografts occurred sooner in younger patients. The same finding has long been reported for aortic homografts ${ }^{21}$ and bioprostheses. ${ }^{19}$

Structural valve deterioration was more frequently noted and mitral stenosis was more pronounced in total homografts than in partial replacements (Tables 1 and E2). This can be explained by the faster deterioration of the cryopreserved homologous valvular tissue compared with the remnants of the native valve in partial homografts. In case of a hemivalve replacement, fibrocalcareous involvement of the partial homograft was commonly observed, whereas the opposite commissural area made from native tissue was oftentimes healthy and opened widely in diastole. The lower incidence of structural deterioration in patients with endocarditis was probably related to the preferential use of a partial homograft in this subgroup.

Likewise, insertion of a small ring (intercommissural distance $\leq 30 \mathrm{~mm}$ ) was associated with a more rapidly occurring stenosis (Table 1). It is difficult to discriminate the impact of the small ring size from that of the other parameters; indeed, patients aged less than 40 years, which included children, and those with a total homograft had smaller ring size than older patients and those who received a partial homograft.

In women of childbearing age, the choice of a mitral homograft as a valve substitute was thought to be appropriate. The lack of oral anticoagulation clearly facilitated normal pregnancies in this series. On the other hand, structural deterioration of the mitral homograft developed in two thirds of women who experienced pregnancy (Table E2). The same trend has been reported for bioprostheses. ${ }^{22}$

In this study, diagnosis of structural deterioration did not rely only on the aspect of the valve at reoperation; patients with gross leaflet thickening or calcification together with severe dysfunction on follow-up echocardiography also were considered. ${ }^{9}$ Altogether, freedom from structural deterioration of the mitral homograft was $76 \%$ at 10 years. In comparison, freedom from structural deterioration of mitral bioprostheses in the study by Jamieson and colleagues ${ }^{19}$ was $60 \%$ for porcine and $80 \%$ for pericardial bioprostheses at 10 years in patients aged less than 40 years. Tanaka and colleagues $^{23}$ reported lower freedom from structural 

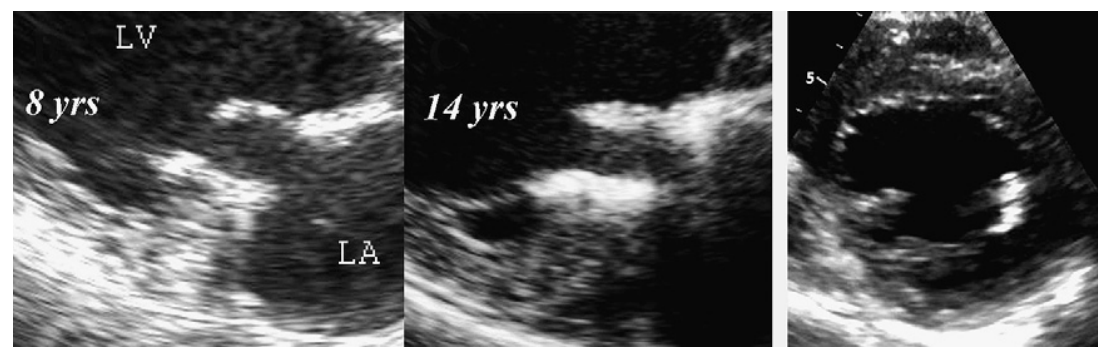

FIGURE 5. Echocardiography in mitral homograft degeneration. Left: Progression of leaflet degeneration with time; leaflet thickening is already visible at 8 years and then dramatically worsens by 14 years. Right: Hyperechogenicity of the grafted papillary muscle after partial mitral homograft with normal aspect of the opposite muscle. $L V$, Left ventricle; $L A$, left atrium.

deterioration rates for the same age range. In these studies, only structural valve deterioration noted at reoperation was considered (no inclusion on echocardiography criteria). Thus, the structural deterioration rate of mitral homografts seems comparable to that of the best existing biological valve substitutes. Nevertheless, because the implantation technique of the mitral homograft is more challenging and carries a risk of early failure that does not exist with bioprostheses, its use cannot be recommended until a more prolonged durability can reasonably be expected. In our own practice over the past decade, mitral homografts have seldom been used whenever biological mitral valve replacement was needed and bioprostheses were preferred.

\section{CONCLUSIONS}

Pathologic findings on mitral homografts explanted for degeneration are in agreement with observations reported for aortic homografts. ${ }^{24}$ Valve tissue was invaded by a dense fibrosis with a complete loss of the normal trilaminar architecture and scattered with calcium deposits. Except for 1 early explant, which was the site of a severe inflammatory reaction, in a child, the homograft tissue was virtually acellular with no sign of immune-mediated injury. These observations suggest that the actual cryopreservation process used for storing valvular homografts profoundly alters cellular components of the endothelium and collagen matrix. As opposed to the proponents of the immune-induced degeneration theory, we believe that cell viability is an essential prerequisite for valve tissue regeneration. Future direction to extend the longevity of mitral homografts would call for an improvement in the cryopreservation method (temperature, type, and concentration of cryoprotective agents). Alternatively, as suggested by the remarkable lack of valve deterioration in heart transplant recipients, ${ }^{25}$ the use of ultra-fresh homografts inserted within 24 hours after harvesting could be advocated.

\section{References}

1. Sievers HH, Lange PE, Yankah AC, Wessel A, Bernhard A. Allogeneous transplantation of the mitral valve. An open question. Thorac Cardiovasc Surg. 1985; $33: 227-9$.
2. Pomar JL, Mestres CA. Tricuspid valve replacement using a mitral homograft. Surgical technique and initial results. J Heart Valve Dis. 1993;2: 125-8.

3. Revuelta JM, Bernal JM, Rabasa JM. Partial homograft replacement of mitral valve. Lancet. 1994;344:514.

4. Kumar AS, Trehan H. Homograft mitral valve replacement-a case report. J Heart Valve Dis. 1994;3:473-5.

5. Acar C, Farge A, Ramsheyi A, Chachques JC, Mihaileanu S, Gouezo R, et al. Mitral valve replacement using a cryopreserved mitral homograft. Ann Thorac Surg. 1994;57:746-8.

6. Acar C, Tolan M, Berrebi A, Gaer J, Gouezo R, Marchix T, et al. Homograft replacement of the mitral valve. Graft selection, technique of implantation, and results in forty-three patients. J Thorac Cardiovasc Surg. 1996;111: 367-80.

7. Ali M, Iung B, Lansac E, Bruneval P, Acar C. Homograft replacement of the mitral valve: eight-year results. J Thorac Cardiovasc Surg. 2004;128: 529-34.

8. Doty DB, Acar C. Mitral valve replacement with homograft. Ann Thorac Surg. 1998;66:2127-31.

9. Akins CW, Miller DC, Turina MI, Kouchoukos NT, Blackstone EH, Grunkemeier GL, et al; AATS, STS, EACTS Councils, Ad Hoc Committee. Guidelines for reporting mortality and morbidity after cardiac valve interventions. J Thorac Cardiovasc Surg. 2008;135:732-8.

10. Amado-Cattaneo R. Combined mitral and aortic homograft valve replacement for acute bacterial endocarditis. Ann Thorac Surg. 1998;66:267-8.

11. Reardon MJ, Vinnerkvist A, LeMaire SA. Mitral valve homograft for mitra valve replacement in acute bacterial endocarditis. J Heart Valve Dis. 1999;8: 71-3.

12. Plunkett MD, Schneider DJ, Shah JJ, Bash SE, Bond LM, Geiss DM. Homograft replacement of mitral valve in children. Ann Thorac Surg. 1998;66: 849-52.

13. Doty DB, Flores JH, Doty JR, Millar RC. Mitral valve replacement with homograft. Semin Thorac Cardiovasc Surg. 1999;11(Suppl 1):191-3.

14. Gulbins H, Kreuzer E, Uhlig A, Reichart B. Mitral valve surgery utilizing homografts: early results. J Heart Valve Dis. 2000;9:222-9.

15. Yankah AC, Sievers HH, Lange PE, Bernhard A. Clinical report on stentless mitral allografts. J Heart Valve Dis. 1995;4:40-4.

16. Kumar AS, Choudhary SK, Mathur A, Saxena A, Roy R, Chopra P. Homograft mitral valve replacement: five years' results. J Thorac Cardiovasc Surg. 2000; 120:450-8.

17. Gulbins H, Anderson I, Kilian E, Schrepfer S, Uhlig A, Kreuzer E, et al. Five years of experience with mitral valve homografts. Thorac Cardiovasc Surg. 2002;50:223-9.

18. Joudinaud TM, Baron F, Raffoul R, Pagis B, Vergnat M, Parisot C, et al. Redo aortic root surgery for failure of an aortic homograft is a major technical challenge. Eur J Cardiothorac Surg. 2008;33:989-94.

19. Jamieson EWR, Marchand MA, Pelletier CL, Norton R, Pellerin M, Dubiel TW, et al. Structural valve deterioration in mitral replacement surgery: comparison of Carpentier-Edwards supra-annular porcine and Perimount pericardial bioprostheses. J Thorac Cardiovasc Surg. 1999;118: 297-304.

20. Chauvaud S, Waldmann T, d'Attellis N, Bruneval P, Acar C, Gerota J, et al. Homograft replacement of the mitral valve in young recipients: mid-term results. Eur J Cardiothorac Surg. 2003;23:560-6. 
21. O'Brien MF, Harrocks S, Stafford EG, Gardner MA, Pohlner PG, Tesar PJ, et al. The homograft aortic valve: a 29 -year, $99.3 \%$ follow up of 1,022 valve replacements. J Heart Valve Dis. 2001;10:334-44.

22. Hung L, Rahimtoola SH. Prosthetic heart valves and pregnancy. Circulation. 2003;107:1240-6.

23. Tanaka H, Okita Y, Kasegawa H, Takamoto S, Tabayashi K, Yagihara T, et al. The fate of bioprostheses in middle-aged patients: the Japanese experience. J Heart Valve Dis. 2010;19:561-7.
24. Koolbergen DR, Hazekamp MG, de Heer E, Bruggemans EF, Huysmans HA, Dion RA, et al. The pathology of fresh and cryopreserved homograft heart valves: an analysis of forty explanted homograft valves. J Thorac Cardiovasc Surg. 2002;124:689-97.

25. Wilhelmi MH, Bara C, Kofidis T, Wilhelmi M, Pichlmaier M, Haverich A. Longterm cardiac allograft valves after heart transplant are functionally and structurally preserved, in contrast to homografts and bioprostheses. $J$ Heart Valve Dis. 2006; 15:777-82.

Access to The Journal of Thoracic and Cardiovascular Surgery Online is reserved for print subscribers!

Full-text access to The Journal of Thoracic and Cardiovascular Surgery Online is available for all print subscribers. To activate your individual online subscription, please visit The Journal of Thoracic and Cardiovascular Surgery Online, point your browser to http://www.mosby.com/jtcvs, follow the prompts to activate your online access, and follow the instructions. To activate your account, you will need your subscriber account number, which you can find on your mailing label (note: the number of digits in your subscriber account number varies from 6 to 10). See the example below in which the subscriber account number has been circled:

\section{Sample mailing label}

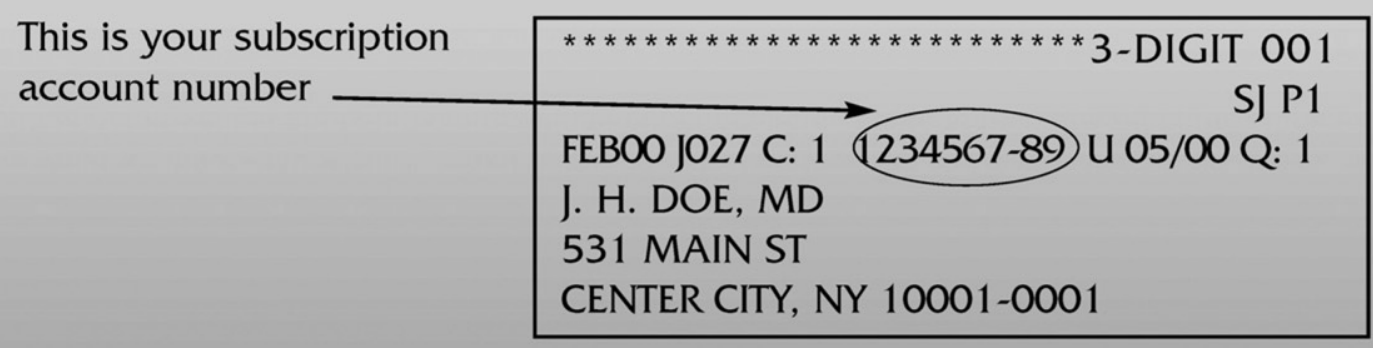

Personal subscriptions to The Journal of Thoracic and Cardiovascular Surgery Online are for individual use only and may not be transferred. Use of The Journal of Thoracic and Cardiovascular Surgery Online is subject to agreement to the terms and conditions as indicated online. 
TABLE E1. Determinants of reoperation in 106 patients with a mitral homograft

\begin{tabular}{lrrc}
\hline \multicolumn{1}{c}{ Reoperation n=35 } & $\mathbf{n}$ & $\%$ & $\boldsymbol{P}$ \\
\hline Age & & & \\
$\quad<40 \mathrm{y}$ & $20 / 57$ & $36.8 \%$ & $P=.46 \mathrm{NS}$ \\
$\quad>40 \mathrm{y}$ & $15 / 49$ & $30.6 \%$ & \\
Homograft technique & & & \\
$\quad$ Total & $26 / 66$ & $39.4 \%$ & $P=.07 \mathrm{NS}$ \\
$\quad$ Partial & $9 / 40$ & $22.5 \%$ & \\
Ring size & & & \\
$\quad \leq 30 \mathrm{~mm}$ & $18 / 49$ & $36.7 \%$ & $P=.45 \mathrm{NS}$ \\
$\quad>30 \mathrm{~mm}$ & $17 / 57$ & $29.8 \%$ & \\
Associated aortic valve surgery & & & \\
$\quad$ Yes & $7 / 15$ & $46.7 \%$ & $P=.23 \mathrm{NS}$ \\
$\quad$ No & $28 / 91$ & $30.8 \%$ & \\
Endocarditis as primary indication & & & \\
$\quad$ Yes & $6 / 24$ & $25.0 \%$ & $P=.34 \mathrm{NS}$ \\
$\quad$ No & $29 / 82$ & $35.3 \%$ & \\
Pregnancy & & & \\
$\quad$ Yes & $3 / 9$ & $33.3 \%$ & $P=.98 \mathrm{NS}$ \\
$\quad$ No & $32 / 97$ & $40.0 \%$ & \\
\hline
\end{tabular}

NS, Not significant.

TABLE E2. Determinants of structural valve deterioration in $\mathbf{1 0 6}$ patients with a mitral homograft

\begin{tabular}{lrrr}
\hline \multicolumn{1}{c}{$\begin{array}{c}\text { Structural valve } \\
\text { deterioration } \mathbf{N}=\mathbf{3 3}\end{array}$} & $\mathbf{n}$ & $\%$ & $\boldsymbol{P}$ \\
\hline Age & & & \\
$\quad<40 \mathrm{y}$ & $21 / 57$ & $36.8 \%$ & $P=.17 \mathrm{NS}$ \\
$\quad>40 \mathrm{y}$ & $12 / 49$ & $24.5 \%$ & \\
Homograft technique & & & \\
$\quad$ Total & $26 / 66$ & $39.3 \%$ & $P=.018$ \\
$\quad$ Partial & $7 / 40$ & $17.5 \%$ & \\
Ring size & & & \\
$\quad \leq 30 \mathrm{~mm}$ & $13 / 49$ & $26.5 \%$ & $P=.34 \mathrm{NS}$ \\
$\quad>30 \mathrm{~mm}$ & $20 / 57$ & $35.1 \%$ & \\
Associated aortic valve surgery & & & \\
$\quad$ Yes & $4 / 15$ & $26.6 \%$ & $P=.68 \mathrm{NS}$ \\
$\quad$ No & $29 / 91$ & $31.9 \%$ & \\
Endocarditis as primary indication & & & \\
$\quad$ Yes & $3 / 24$ & $12.5 \%$ & $P=.02$ \\
$\quad$ No & $30 / 82$ & $36.6 \%$ & \\
Pregnancy & & & \\
$\quad$ Yes & $6 / 9$ & $66.7 \%$ & $P=.016$ \\
$\quad$ No & $27 / 97$ & $27.8 \%$ & \\
\hline
\end{tabular}

NS, Not significant. 